\title{
PENINGKATAN KOMPETENSI GURU SEKOLAH DASAR BUDI MULIA DUA SETURAN, DEPOK, SLEMAN
}

\author{
Ristiyani, Wiwik Wijayanti \\ SD Negeri Ngijon 3 Moyudan Sleman, Universitas Negeri Yogyakarta \\ ristiyani.@yahoo.com,wiwikwijayanti@uny.ac.id
}

\begin{abstract}
Abstrak
Penelitian ini bertujuan mendeskripsikan: (1) upaya yang dilakukan kepala sekolah dan guru untuk meningkatkan kompetensi, (2) faktor pendukung dan penghambat peningkatan kompetensi guru serta cara mengatasi hambatan tersebut. Penelitian ini menggunakan pendekatan kualitatif jenis studi kasus. Subyek atau sumber data dalam penelitian ini terdiri dari kepala sekolah, guru senior, guru menengah/madya, guru yunior, staf penelitian dan pengembangan, staf pengembangan sumber daya manusia dan staf administrasi sekolah. Teknik pengumpulan data yang digunakan yaitu observasi, wawancara dan dokumentasi. Teknik analisis data dalam penelitian ini menggunakan model interaktif mengacu pada teknik analisis data kualitatif Miles dan Huberman yaitu: reduksi data, penyajian data, dan penarikan kesimpulan/verifikasi. Hasil penelitian menunjukkan bahwa upaya yang dilakukan kepala sekolah mengirim guru mengikuti pelatihan dan kegiatan ilmiah, mengadakan sosialisasi hasil pelatihan, memotivasi peningkatkan kompetensi, memberikan reward. Upaya para guru yaitu memahami tuntutan standar profesi, etos kerja dan budaya kerja. Upaya kepala sekolah mengatasi hambatan yaitu memfasilitasi pengembangan profesi, untuk mengatasi hambatan waktu pelatihan dengan mengadakan pemetaan kebutuhan guru yang dikirim, membuat jadwal pengganti bagi guru yang diikutsertakan ke pelatihan, membuat jadwal tersendiri di luar jam pembelajaran. Upaya para guru dalam mengatasi hambatan diantaranya melanjutkan ke Strata-2, keikutsertaan pelatihan dan kegiatan ilmiah. Upaya para guru mengatasi hambatan waktu pelatihan yaitu antara guru saling menukar jadwal mengajar. Alternatif lain adalah memberikan tugas ke siswa.
\end{abstract}

Kata kunci: upaya, peningkatan kompetensi, profesionalisme guru.

\section{IMPROVING THE COMPETENCE OF THE TEACHERS OF ELEMENTARY SCHOOL BUDI MULIA DUA SETURAN, DEPOK, SLEMAN}

\begin{abstract}
This study aims to describe: (1) the efforts of the principals and teachers to improve the teachers' competence, (2) the supporting and inhibiting factors in the teachers' competence improvement and their solution. This study was a case study using the qualitative approach. The subjects consisted of the principal, two senior teachers, two intermediate teachers, two junior teachers, research and development staff, human resource development staff and school administrative staff. The data collection techniques used were observation, interview, and documentation. The data analysis technique used was an interactive model techniques of Miles and Huberman including data reduction, data display, and conclusion. The results showed that the efforts made by principals included sending the teachers to participate in training and scientific activities, holding socialization of the training outcomes, motivating the teachers to improve their competence and providing rewards. Efforts made by teachers were to understand the demands of professional standards, developing working ethics and culture. Efforts made by the principal to overcome the barriers were by facilitating teachers to conduct professional development. The efforts to overcome the barriers of time was done by mapping the needs of teachers to be sent, by rescheduling teachers who participate to the training, by providing a special schedule out of learning hours. The efforts made by the teachers to overcome barriers were by continuing to S-2 (Magister program), participating training and scientific activities, while the efforts made by teachers to overcome that problem were by exchanging teaching schedule. The alternative way of exchanging teaching was done to give assignments to students.
\end{abstract}

Keywords: efforts, teachers' competence, teachers' professionalism 


\section{Pendahuluan}

Kompetensi diartikan oleh Cowwell (Hasanah, A. 2012, p. 40) sebagai suatu keterampilan/kemahiran yang bersifat aktif. Kompetensi dikategorikan mulai dari tingkat sederhana atau dasar hingga lebih sulit atau komplek yang pada gilirannya akan berhubungan dengan proses penyusunan bahan atau pengalaman belajar yang lazimnya terdiri atas; (a) penguasaan minimal kompetensi dasar; (b) praktik kompetensi dasar; (c) penambahan penyempurnaan atau pengembangan terhadap kompetensi atau keterampilan.

Tiga nilai utama yang penting untuk mengajar yang profesional abad ke-21: berpusat pada pelajar, identitas guru, dan pelayanan kepada profesi dan masyarakat. Nilai-nilai ini membimbing penerapan keterampilan dan pengetahuan yang relevan dalam kehidupan sehari-hari. Guru saat ini perlu mengembangkan keterampilan untuk mengajar dan berpikir, administrasi dan manajemen, serta pengetahuan diri dan murid, masyarakat dan pedagogi, di antara banyak lainnya (Darling-Hammond (2010, p. 1)

Sekolah Dasar Budi Mulia Dua menjawab permasalahan pendidikan dengan menyediakan sumber daya manusia (SDM) yang bermutu, yaitu dengan menyiapkan pegawai yang profesional dan kompeten. Visi Sekolah Dasar Budi Mulia Dua adalah mendampingi anak dalam belajar dan mengembangkan potensinya untuk menjadi manusia yang berakhlak mulia, cerdas dan terampil serta pendidikan yang berbasis Living Value. Kurikulum Sekolah Dasar Budi Mulia Dua berpedoman pada kurikulum Kementrian Pendidikan Nasional yang dikembangkan sendiri oleh Perguruan Budi Mulia Dua. Kurikulum yang dikembangkan menggunakan metode "Happy Learning", adalah sebuah metode yang menciptakan suasana proses belajar mengajar yang menarik, menyenangkan dan dapat memberi tantangan serta motivasi pada anak untuk aktif, mempunyai rasa ingin tahu, dan kreatif.

Metode Happy learning dikembangkan untuk mengajarkan siswa supaya men- jadi pelajar mandiri, perlu di dukung oleh guru yang profesional. Sebaik apapun kurikulum diciptakan tidak akan berhasil baik tanpa adanya dukungan guru yang profesional. Sekolah Dasar Budi Mulia untuk mendapatkan guru yang profesional diawali dari proses rekruitmen yang sangat ketat. Proses rekruitmen tersebut tidak membatasi dari mana asal pendidikan dan dari bidang keilmuan apa guru berasal. Teori bisa dipelajari, skill bisa diolah.

Misi Sekolah Dasar Budi Mulia yaitu: (1) membantu anak tumbuh dan berkembang sesuai dengan potensinya, (2) memberikan pendidikan dasar dengan kurikulum yang tidak membebani siswa, (3) menyediakan sarana dan prasarana yang membuat anak menyukai sekolah dengan hati senang.

Berdasarkan hasil pra survai memperoleh informasi bahwa Sekolah Dasar Budi Mulia Dua memiliki 67 guru, 18 guru pilihan dan 17 karyawan. Sebutan untuk guru perempuan dengan "Miss" dan sebutan guru laki-laki dengan "Mister", karena sebagian siswa ada yang berasal dari luar negeri. Adanya suasana sekolah yang kondusif, termasuk di dalamnya keberadaan guru yang memiliki disiplin tinggi dalam menjalankan tugas dan memiliki kinerja yang cukup baik. Hal tersebut dikarenakan adanya pembinaan yang dilakukan kepala sekolah sebagai pimpinan yang bertanggung jawab terhadap kualitas warga sekolah. Keberadaan guru Budi Mulia yang memiliki kualifikasi pendidikan mismatch dengan pendidikan di Sekolah Dasar, sekolah dapat melatihnya menjadi guru yang profesional dan kompeten, yang berdampak pada terciptanya pembelajaran yang berkualitas sehingga dapat menghasilkan lulusan yang unggul dalam bidang akademik, bidang sosial maupun keterampilan adalah suatu tantangan menarik untuk diteliti.

Sekolah Dasar Budi Mulia dua menyelenggarakan kegiatan peningkatan kompetensi guru dalam bentuk pelatihan. Pelatihan diselenggarakan untuk para guru baik guru mismach maupun guru yang sesuai dengan bidang keilmuannya. Ke- 
giatan yang diselenggarakan ini merupakan hasil rekomendasi kepala sekolah, bagian (SDM), bagian penelitian dan pengembangan serta biaya dibebankan pada RAPBS. Adanya guru yang mismatch tetapi dapat menjadi guru yang profesional dan kompeten menjadi sesuatu yang menarik untuk diteliti.

Berangkat dari hal tersebut peneliti tertarik untuk meneliti lebih lanjut bagaimana upaya kepala sekolah dalam meningkatkan kompetensi guru di Sekolah Dasar Budi Mulia Dua Seturan Depok Sleman, seperti tertuang dalam judul penelitian "Peningkatan Kompetensi Guru Sekolah Dasar Budi Mulia Dua Seturan Depok Sleman".

\section{Metode Penelitian}

Jenis Penelitian

Penelitian ini menggunakan Pendekatan Kualitatif jenis studi kasus. Sevilla, et al.( Bungin, 2012:19) bila kita melakukan penelitian yang terinci tentang seseorang (individu) atau sesuatu unit sosial selama kurun waktu tertentu, kita melakukan apa yang disebut studi kasus. Pemilihan pendekatan dalam penelitian ini didasarkan atas pertimbangan bahan penelitian ini bukan penelitian untuk menguji hipotesis tetapi bertujuan untuk mengetahui peningkatan kompetensi guru di Sekolah Dasar Budi Mulia Dua Seturan Depok Sleman.

\section{Tempat dan Waktu Penelitian}

Lokasi atau tempat penelitian ini dilakukan di Sekolah Dasar Budi Mulia Dua beralamat di Jalan Seturan Nomor 15 Catur Tunggal Depok Sleman. Adapun waktu penelitian dilaksanakan pada bulan Oktober sampai Desember 2013 dan akan diperpanjang sampai dengan selesai penelitian.

\section{Sumber Data Penelitian}

Untuk memperoleh data dan informasi sesuai yang diharapkan dalam penelitian, maka subyek yang diambil adalah orang-orang yang dianggap berkompeten dan mampu memberikan informasi sesuai dengan permasalahan penelitian. Jumlah responden yang diambil dalam penelitian ini terdiri dari seorang kepala sekolah, 2 guru senior, 2 guru menengah/madya, 2 guru yunior, seorang staf litbang, seorang staf pengembangan sumber daya manusia dan staf administrasi sekolah untuk dijadikan informan penelitian.

Teknik Pengumpulan Data dan Teknik Analisis Data

Teknik pengumpulan data yang digunakan dalam penelitian ini dilakukan melalui 3 cara, yaitu observasi, wawancara dan dokumentasi.

Teknik analisis data yang digunakan dalam penelitian ini mengacu Model interaktif oleh Miles dan Huberman (1992: 16) analisis data dalam penelitian kualitatif terdiri dari tiga alur kegiatan yang terjadi secara bersamaan, yaitu: reduksi data, penyajian data, dan penarikan kesimpulan/ verifikasi.

\section{Hasil Penelitian dan Pembahasan}

Upaya Kepala Sekolah Dalam Peningkatan Kompetensi Di SD Budi Mulia Dua Seturan Depok Sleman

Berdasarkan hasil penelitian, upaya kepala sekolah dalam peningkatan kompetensi guru di Sekolah Dasar Budi Mulia Dua Seturan Depok Sleman adalah sebagai berikut:

Kepala Sekolah Mengirimkan Guru ke Pelatihan, Penataran, Lokakarya, Workshop, dan Seminar untuk Meningkatkan Kompetensinya.

Kepala sekolah Sekolah Dasar Budi Mulia mewajibkan para guru mengikuti pelatihan dan pembinaan yang diselenggarakan oleh Dinas Pendidikan Propinsi DIY, Dinas Pendidikan Pemuda dan Olahraga Kabupaten Sleman, LPMP, P4TK, UGM, UNY maupun yang diselenggarakan oleh lembaga swasta.

Hal tersebut seperti diungkapkan oleh Miss OS (07-10-2013) salah satu guru Matematika, seperti berikut: 
Seminar, workshop. Ya, selalu ada satu guru yang diikutkan pelatihan. Saat ini ada pelatihan Matematika dari P4TK selama 20 hari dan Budi Mulia mewakilkan satu orang guru matematika kelas 5 se ASEAN, namanya SEAMEO.

Mister EB mengemukan: "Ya, dengan mengirim guru ke pelatihan-pelatihan workshop, atau melanjutkan studi."

Pernyataan di atas sebagai bukti bahwa para guru mata pelajaran sering diikutsertakan dalam kegiatan pelatihan dan pembinaan yang menunjang peningkatan kompetensi guru di SD Budi Mulia Dua Seturan Depok Sleman. Setiap ada kesempatan bagi para guru, Kepala Sekolah SD Budi Mulia selalu mengirimkan guru atau tenaga administrasi untuk mengikuti pelatihan, seminar, penataran, lokakarya, workshop, studi banding dan melanjutkan studi ke jenjang Strata-2.

Hasil penelitian mengungkapkan bahwa para guru di Sekolah Dasar Budi Mulia sudah diikutsertakan ke pelatihan sesuai dengan bidang keahliannya. Kriteria guru yang dikirim berdasarkan hasil seleksi dari kepala sekolah dan merupakan hasil pemetaan kebutuhan guru akan pelatihan.

Mengadakan Sosialisasi Hasil Pelatihan, Penataran, Lokakarya, Workshop, dan Seminar

Sosialisasi hasil pelatihan diselenggarakan pada waktu rapat koordinasi bulanan, rapat rumpun guru bidang studi, atau sosialisasi diadakan pada saat rapat kerja setiap akhir semester. Hal tersebut seperti dikemukakan kepala sekolah (0611-2013) sebagai berikut:

Setiap guru yang dikirim ke pelatihan berkewajiban untuk mensosialisasikan hasil pelatihannya kepada guru lain yang serumpun. Hal ini dilakukan pada saat rapat koordinasi bulanan, rapat rumpun guru bidang studi, atau pada saat rapat kerja setiap akhir semester.

Sosialisasi hasil pelatihan disampaikan oleh guru yang dikirim ke pelatihan, tujuannya agar guru yang tidak mengikuti pelatihan juga mendapatkan ilmu seperti guru yang dilatih. Dengan semakin banyak guru yang dikirim akan banyak pula ilmu yang diserap oleh para guru, sehingga wawasan keilmuan, pengetahuan, keterampilan mengajar guru menjadi meningkat.

Menyelenggarakan Diklat di Lingkungan Sekolah

Diklat yang diselenggarakan di lingkungan sekolah ada berbagai macam jenisnya antara lain:

\section{1) Pelatihan Pembuatan RPP}

Pelatihan pembuatan RPP diselenggarakan oleh masing-masing rumpun yang terdiri dari rumpun Matematika, rumpun IPS, rumpun IPA, rumpun Pkn, rumpun Bahasa Indonesia, rumpun Kemahiran Hidup, rumpun Kebudayaan Jawa, rumpun Olah Raga, rumpun Inklusi dan lain sebagainya. Pelatihan pembuatan RPP diadakan di awal tahun ajaran dan menjadi satu paket dengan pembuatan silabus. RPP di buat oleh masing-masing guru, sedangkan silabus dibuat bersama dalam pertemuan rumpun.

Kepala sekolah (06-11-2013) mengemukakan tentang hal tersebut sebagai berikut:

$B M D$ menyelenggarakan diklat di lingkungan sekolah yang meliputi: pelatihan "pembuatan RPP", pelatihan "mengajar dengan hati", pelatihan "manajamen konflik", pelatihan "vision alignment"dll.

Sedangkan Mister SN mengemukakan tentang adanya pertemuan rumpun di Budi Mulia yang membahas tentang soal UTS, UAS, Uji Kompetensi, cara membuat raport narasi, dan membuat silabus sebagai berikut:

Ada pertemuan rumpun, setiap satu semester 4-5 kali. Ada pertemuan rumpun perbidang studi. Saya mengikuti pertemuan rumpun matematika yang membahas: (1) soal UTS, UAS, uji kompetensi (2) narasi, membahas bagaimana guru membuat raport narasi atau membahasakan, antara guru saling koreksi. Setelah itu diperiksakan kepala sekolah. Jadi raport yang sampai ke orang tua sudah melalui beberapa tahap seleksi harapannya raport yang diberikan ke orang tua sudah benar baik 
dari segi penulisan maupun bahasanya. (3) Silabus dibuat bersama pada saat pertemuan rumpun, tetapi RPPdibuat sendiri oleh masing-masing guru. Silabus dibuat pertema-tema disusun per rumpun, hasil dipakai bersama. RPP yang dibuat pribadi karena tergantung sekolah masing-masing."

\section{2) Pelatihan Pembuatan Silabus}

Pelatihan pembuatan silabus merupakan satu paket dengan pelatihan pembuatan RPP yang dilaksanakan pada awal pembelajaran. Berdasarkan hasil penelitian, RPP yang digunakan di dibuat sendiri oleh masing-masing guru, sedangkan silabus dibuat bersama oleh guru dan digunakan secara bersama pula. Guru wajib mengumpulkan RPP sebelum pembelajaran awal semester dimulai. Dengan demikian ketika pembelajaran awal semester dimulai para guru sudah siap melaksanakan RPP yang telah selesai dibuat.

\section{3) Pelatihan Mengajar dengan Hati}

Pelatihan mengajar dengan hati diberikan oleh Prof. Marsudi Kisworo tentang cara menjadi guru kreatif yang mengajar dengan sepenuh hati. Pada pelatihan tersebut dibahas pula tentang peran guru sebagai motivator dan teladan bagi para siswa.

\section{4) Pelatihan Manajamen Konflik,}

Pelatihan manajemen konflik adalah suatu pelatihan yang mengajarkan kepada guru atau karyawan tentang cara mengatasi permasalahan pekerjaan yang di hadapi, menghadapi siswa dikelas, menghadapi rekan kerja, menghadapi pimpinan, dan melayani wali murid sebagai pelanggan langsung.

\section{5) Pelatihan Vision Alignment}

Pelatihan Vision Alignment bertujuan untuk menyegarkan kembali atau membawa kembali ke visi sekolah Budi Mulia Dua. Selain itu pelatihan berisi cara penanganan siswa, berupa memanusiakan siswa, yaitu bagaimana seharusnya seorang guru memperlakukan para siswa, dengan metode paling tepat. Dengan pelatihan $\mathrm{Vi}$ - sion Alignment para guru diajak kembali ke visi misi Sekolah Dasar Budi Mulia Dua, agar senatiasa ingatakan tanggung jawab tentang tugasnya. Pelatihan diselenggarakan setiap semester minimal dua kali dalam setahun dengan evaluasi, rekomendasi dan ada monitoring.

6) Pelatihan Olimpiade Matematika

Pelatihan Olimpiade Matematika merupakan pelatihan hasil kerja sama antara Sekolah Dasar Budi Mulia Dua dengan Sekolah Dasar Muhammadiyah Condong Catur. Tujuan jangka panjang diadakannya pelatihan Olimpiade Matematika yaitu menyiapkan siswa-siswa untuk mengikuti lomba Olimpiade yang diselenggarakan oleh Dinas Pendidikan Pemuda dan Olahraga Kabupaten Sleman setiap tahunnya. Berbagai usaha yang dilakukan diantaranya dengan menyiapkan para guru untuk dilatih.

\section{7) Workshop Penulisan Narasi}

Pada workshop penulisan narasi diselenggarakan di lingkungan sekolah untuk melatih, memperdalam wawasan dan ketrampilan guru dalam membuat raport. Di Sekolah Dasar Budi Mulia Dua selain raport angka juga ada raport narasi, untuk itu guru perlu dilatih untuk membuatnya. Membuat raport ada dua kriteria yaitu nilai angka dan nilai usaha. Nilai usaha adalah usaha-usaha yang dilakukan siswa untuk mencapai suatu nilai tertentu, tugas guru adalah membuat ilustrasi tersebut yaitu menilai segala kelebihan, kekurangan, dan saran-saran bagi siswa.

SD Budi Mulia Dua bukan hanya mengembangkan pembelajaran yang mengarah ke kognitif saja tetapi aspek-aspek kepribadian terutama aspek intelektual, sosial, emosional, dan ketrampilan juga dikembangkan. Untuk itu raport narasi menjadi sangat penting dibuat.

8) Pelatihan Bahasa Inggris untuk Guru dan Karyawan

Bagian personalia atau SDM mengemukakan bahwa di SD Budi Mulia memiliki Language House, para guru di pretes kemudian diklasifikasi sesuai kemampuan 
yang diperoleh. Guru sebenarnya antusias mengikuti pelatihan dan membutuhkan pengetahuan tentang Bahasa Inggris. Alasannya karena siswa-siswa dari Budi Mulia ada yang berasal dari Luar Negeri. Para guru difasilitasi pelatihan dari LIA, tetapi pelatihan Bahasa Inggris tidak berlanjut karena manajemen pelatihan dari LIA yang kurang profesional.

\section{9) Pelatihan Teknologi Informasi}

Pelatihan komputer digunakan guru dalam mempresentasikan program-programnya ketika ada rapat kerja (raker) yang diadakan Sekokah Dasar Budi Mulia Dua setiap akhir semester maupun awal semester. Pelatihan diselenggarakan satu kali setiap Minggu pada hari Jum'at setelah selesai pembelajaran.

Materi pelatihan antara lain MS Office, Power Point, Mail Marge, Gif, Ispring, dan Quis Creator.

Berdasarkan hasil penelitian, pelatihan komputer sangat bermanfaat sekali bagi para guru dalam meningkatkan kompetensi mengajarnya. Para guru harus selalu update pengetahuan dan mengikuti perkembangan teknologi terkini. Kendala dalam pelatihan komputer yaitu ada beberapa guru yang tidak menyiapkan perangkat pembelajaran (laptop) dalam pelatihan tersebut sehingga pelatihan kurang maksimal.

Memotivasi untuk Meningkatkan Kompetensi bagi Guru

Kepala sekolah selalu memotivasi para guru untuk meningkatkan kompetensinya. Berdasarkan data hasil penelitian terungkap bahwa cara kepala sekolah memotivasi para guru meningkatkan kompetensinya diantaranya sebagai berikut.

Pertama, sebagai seorang guru harus lebih pintar dari muridnya, guru harus selalu memperbaharui ilmunya dengan membaca dan belajar karena pendidikan di SD adalah investasi jangka panjang yang akan dipetik hasilnya 30 tahun yang akan datang. Anak-anak akan menjadi pemimpin bangsa 30-40 tahun yang akan datang.
Kedua, Bekerja sebagai guru adalah ibadah untuk mendapatkan kunci surga melalui do'a anak-anak yang soleh. Jika guru berhasil mencetak anak-anak yang sholeh maka insyaAllah mereka nanti akan selalu mendoakan kita (gurunya) bahkan ketika kita sudah meninggal. Cara lain kepala sekolah memotivasi guru yaitu dengan meminjamkan buku-buku koleksi pribadinya. Begitulah berbagai cara yang dilakukan kepala sekolah untuk memotivasi guru meningkatkan kompetensinya.

Mengadakan Studi Banding ke Sekolah Lain yang Lebih Maju.

Sekolah Budi Mulia mengirim guru untuk studi banding ke sekolah lain baik di dalam maupun di luar negeri. Studi banding di dalam negeri antara lain ke SD Mutiara Bunda Bandung, SD Al-Jannah Bogor, SD Jubilee Jakarta, MIN Malang dan lain sebagainya. Sedangkan ke luar negeri antara lain ke Singapura, Malaysia, Jepang, dan lainnya. Studi banding dilakukan untuk menambah wawasan tentang pembelajaran, manajemen sekolahnya, keadaan sekolah yang dikunjungi, sarana prasarana, mempelajari latar belakang ekonomi, sosial budaya di sekolah tersebut, prestasi sekolah dan sebagainya. Banyak manfaat yang bisa diambil dengan mengirim guru studi banding. Sekolah akan semakin kompetitif dan mampu menciptakan pendidikan yang bermutu.

Mengirim Guru Budi Mulia untuk Magang Kerja ke Sekolah Lain yang Lebih Maju

Sekolah Budi Mulia mengirim guru untuk magang kerja ke sekolah lain yang lebih maju untuk melihat lebih dekat sekolah tersebut tentang kurikulumnya, pembiasaan kegiatan keagamaan, kegiatan belajar mengajarnya, kebersihannya, tentang hal-hal yang bisa diterapkan di Sekolah Dasar Budi Mulia Dua. Dengan pengiriman guru untuk magang kerja ke sekolah lain yang lebih maju, diharapkan dapat membawa ilmu baru, pengalaman dan wawasan baru yang nantinya bisa diterapkan di Sekolah Dasar Budi Mulia Dua. 
Melengkapi Sarana dan Berbagai Media Penunjang Kegiatan Pembelajaran

Sekolah Budi Mulia selalu melengkapi sarana dan berbagai media penunjang kegiatan pembelajaran antara lain melengkapi LCD untuk setiap kelas, wifi dan internet, melengkapi sarana dan media penunjang yang lain dengan berkoordinasi ke bagian alat peraga yaitu Miss H. Perangkat LCD di Sekolah Dasar Budi Mulia Dua untuk kelas 1,2, dan 3 satu grade satu LCD dan untuk kelas 4,5,6 masing-masing kelas sudah dipasang perangkat LCD dan ada fasilitas Wifi. Guru sangat terbantukan dengan adanya LCD, komputer dan sebagainya.

Buku-buku penunjang serta alat peraga sangat lengkap dan memadai, karena selain diusahakan oleh sekolah juga mendapat bantuan dari Dinas Pendidikan Pemuda dan Olahraga kabupaten Sleman terutama buku-buku pegangan guru dan siswa untuk pelaksanaan kurikulum 2013. Sedangkan alat peraga Matematika mendapat batuan dari PPPPTK.

Memberikan Penghargaan bagi Guru Sekolah Dasar Budi Mulia yang Berprestasi

Para guru Budi Mulia yang berprestasi akan mendapatkan reward dari perguruan antara lain umroh, uang sebesar satu kali gaji, dan beasiswa untuk putra putri mereka. Ada penilaian dihubungkan dengan reward yang disebut PKG/penilaian kinerja guru, yaitu menilai tugas-tugas yang dilaksanakan guru misalnya Administrasi, supervisi, dan sistem pembelajaran yang dilakukan guru. Reward berupa: (1) Uang sebesar satu kali gaji, (2) Umroh, berdasarkan masa kerja minimal 5 tahun, (3) Beasiswa untuk putra-putri guru, khusus TK dan SD. Reward berupa insentif diberikan kepada guru dalam empat periode pertahun, reward rekreasi keluarga dilakukan lima tahun sekali. Sedangkan reward berupa umroh dilakukan per tahun empat guru setiap tahunnya. Sekolah juga memberikan reward yang diberikan secara insidental terhadap guru yang berprestasi.
Kepala Sekolah Memberi Izin Belajar bagi para Guru atau Tenaga Kependidikan Lainnya untuk Melanjutkan studi

Kepala sekolah memberi izin belajar bagi guru-guru atau tenaga kependidikan lainnya untuk melanjutkan pendidikan ke jenjang Strata-2 sesuai bidang keilmuannya. Pemberian beasiswa bagi guru merupakan wujud nyata dukungan sekolah terhadap keinginan kuat guru untuk melanjutkan studi ke strata yang lebih tinggi yaitu dengan memfasilitasi, memotivasi, dan menunjukkan alternatif yang terbaik bagi guru.

Dari hasil penelitian ada beberapa guru yang belum mengetahui tentang adanya program beasiswa dari perguruan. Guru tersebut belum mengetahui jika perguruan memberikan beasiswa dengan persyaratan tertentu yaitu masa kerja minimal lima tahun, belum pernah cuti di luar tanggungan dan dari penilaian hasil supervisi kepala sekolah. Adapun para guru yang belum mengetahui tentang adanya program beasiswa dari sekolah tersebut karena adanya informasi yang belum sampai ke semua guru.

Guru Diwajibkan Mengikuti KKG, Pertemuan Rumpun, dan Pertemuan Grade

Para guru Budi Mulia diwajibkan mengikuti kegiatan-kegiatan yang menunjang keprofesian seorang guru, diantaranya mengikuti kegiatan KKG, pertemuan rumpun per bidang studi, dan pertemuan grade.

Guru Diwajibkan Mengikuti Sosialisasi Kurikulum 2013 yang Dilaksanakan oleh Dinas Pendidikan Pemuda dan Olahraga Kabupaten Sleman

Sekolah Dasar Budi Mulia Dua merupakan salah satu sekolah yang ditunjuk oleh Dinas Pendidikan Pemuda dan Olahraga Kabupaten Sleman untuk menjadi pilot proyek pelaksanaan kurikulum 2013. Para guru diberi pelatihan mengenai kesiapan pelaksanaan kurikulum 2013 oleh LPMP Propinsi DIY, mulai dari pendampingan bagi guru, pelatihan tentang kurikulum 2013, bentuk implementasi, bentuk 
penilaiannya, bentuk rapornya dan lain sebagainya. Sekolah Dasar Budi Mulia Dua ternyata sudah lebih dahulu melaksanakan kurikulum 2013, bahkan raport sudah mulai narasi, hampir sama tetapi memakai deskripsi. Yang diterapkan di Sekolah Dasar Budi Mulia Dua sudah merupakan bentuk aplikatif dari kurikulum 2013 dan teori-teorinya bisa diterapkan dengan cara yang lebih sederhana

Berdasarkan hasil penelitian, upaya kepala sekolah dalam peningkatan kompetensi di Sekolah Dasar Budi Mulia Dua Seturan Depok Sleman ternyata sesuai dengan teori yang dikemukakan oleh Aan Hasanah (2012, p.50) yang menyatakan bahwa upaya yang dilakukan oleh kepala sekolah dalam membina dan meningkatkan kompetensi guru antara lain berupa: (1) mengirim guru untuk mengikuti pelatihan, penataran, lokakarya, workshop, dan seminar; (2) mengadakan sosialisasi hasil pelatihan dan berbagai kebijakan pemerintah dengan mendatangkan narasumber; (3) mengadakan pelatihan komputer dan bahasa Inggris; (4) mendorong guru untuk melanjutkan studi agar sesuai dengan tuntutan pemerintah; (5) mengadakan studi banding ke sekolah lain yang dipandang lebih maju; (6) mengirim guru untuk magang kerja ke sekolah lain; (7) melengkapi sarana dan berbagi media penunjang kegiatan pembelajaran; (8) memberikan penghargaan bagi guru yang berprestasi; (9) Meningkatkan kesejahteraan guru dengan memberikan tambahan pendapatan yang bersumber dari komite sekolah dan orang tua siswa; (10) memberikan keteladanan, dorongan, dan menggugah hati nurani guru agar menyadari tugas dan tanggung jawab sebagai guru.

Teori yang disampaikan Aan Hasanah sesuai dengan temuan penelitian di Sekolah Dasar Budi Mulia Dua, bahkan peneliti menemukan adanya nilai lebih dari hasil penelitian tersebut. Banyak hal yang dilakukan Kepala Sekolah untuk meningkatkan kompetensi guru, sehingga bisa membawa Sekolah Dasar Budi Mulia Dua menjadi Sekolah yang bermutu.
Upaya Guru Dalam Peningkatan Kompetensi Di Sekolah Dasar Budi Mulia Dua Seturan Depok Sleman

Berdasarkan temuan penelitian tersebut, upaya yamg dilakukan guru untuk meningkatkan kompetensinya adalah sebagai berikut.

\section{Memahami Tuntutan Standar Profesi Yang Ada}

Upaya yang dilakukan oleh para guru untuk memahami tuntutan standar profesi yang ada melalui beberapa cara sebagai berikut.

10)Sekolah Budi Mulia selalu memfasilitasi bagi para guru yang ingin meningkatkan kompetensinya melalui melanjutkan studi ke Strata- 2

Di Sekolah Dasar Budi Mulia Dua semua guru sudah memenuhi standar yang di tetapkan pemerintah, karena semua guru yang diterima salah satu persyaratannya adalah minimal memiliki ijazah Strata-1, dan saat ini beberapa guru yang sedang menempuh Strat-2 ada lima orang.

1) Para guru aktif melakukan networking

Salah satu guru bahasa Inggris mengikuti program Virtual Teaching Support Networking (VTSN) Britis Consul di Pustekom, juga ikut Mailis (berbagi informasi), ikut lomba menulis atau membuat karya tulis di Majalah Bobo, lomba guru berprestasi di tingkat kecamatan dan kabupaten.Tingkat kecamatan Depok juara 1 dan untuk tingkat kabupaten Sleman juara 4 di tahun 2013.

2) Para guru selalu belajar dengan ikut pertemuan rumpun, saling sharing dengan guru, kalau untuk perkembangan anak di rapat grade setiap satu Minggu sekali membahas antara lain tentang perkembangan anak, programprogram untuk menghadapi UN.

3) Para guru selalu meningkatkan kompetensi diri, gaul networking, banyak membuka wawasan, banyak membaca, selalu upgrade pengetahuan. 
Mencapai kualifikasi dan kompetensi yang diharapkan

Para guru di Sekolah Dasar Budi Mulia sudah mencapai suatu derajat kriteria profesional yaitu berpendidikan akademik S-1 atau D-IV dan telah lulus uji kompetensi melalui proses sertifikasi.

Para guru di Sekolah Dasar Budi Mulia untuk mencapai kualifikasi dan kompetensi yang diharapkan berusaha untuk: (1) melanjutkan studi ke Strata-2; (2) mengikuti workshop, seminar, pelatihan, lokakarya yang diadakan di sekolah maupun di luar sekolah; (3) mendownload film, game, permainan dari internet agar pembelajaran tidak jenuh; (4) sering membaca atau dituntut tentang mengajar yang baik; (5) Aktif Networking; (6) membuat karya tulis, baik fiksi maupun non fiksi; (7) mengikuti lomba guru berprestasi; (8) mengikuti Mailis (berbagi informasi); (9) mengikuti PLPG; (10) mengambil Program Akta IV; (11) saling sharing dengan guru di grade; (12) Mengikuti pertemuan rumpun per bidang studi

Membangun hubungan kesejawatan yang baik dan luas lewat organisasi profesi

Upaya yang dilakukan guru dalam membangun hubungan kesejawatan yang baik dan luas lewat organisasi profesi adalah dengan:

1) Mengikuti Kegiatan Rumpun Per Bidang Studi.

Salah satu kegiatan di Sekolah Dasar Budi Mulia diantaranya Rumpun Matematika, Rumpun IPA, Rumpun PKn, Rumpun IPS, Rumpun Agama, Rumpun Bahasa Indonesia, Rumpun Bahasa Inggris, dan Rumpun Kamahiran Hidup.Dengan ikut rumpun bisa sharing pengalaman, bagaimana pengalaman mengajar guru, kesulitan-kesulitan dalam menghadapi siswa, mengundang dari LPMP tentang cara membuat penilaian, dan cara membuat KKM.

2) Mengikuti kegiatan guru-guru di Yogyakarta lewat organisasi Ikatan Guru Indonesia (IGI)

Salah satu guru di Sekolah Dasar Budi Mulia cara membangun hubungan kesejawatan yang baik dan luas termasuk lewat organisasi profesi dengan berusaha daftar IGI (Ikatan Guru Indonesia).

Kegiatan yang diikuti oleh guru tersebut merupakan salah satu cara membangun hubungan kesejawatan yang luas lewat organisasi profesi, meskipun guru tersebut belum aktif di dalamnya.

3) Mengikuti kegiatan Mailis dan JETA (Jogja English Teacher Asosiation)

Salah satu guru Bahasa Inggris di Sekolah Dasar Budi Mulia memiliki banyak pengalaman dan kegiatan baik yang di laksanakan di sekolah maupun di luar sekolah. Kegiatannya antara lain aktif networking, mengikuti kegiatan guru pusaka, menjadi pemakalah paralel di JETA, pemateri di hotel Borobudur.

4) Membangun sharing yang baik antara guru ditingkat grade, rumpun, dengan kepala sekolah sampai tingkat perguruan

Salah satu hal yang membuat sukses dan besar sekolah Budi Mulia karena adanya sharing antara guru dengan guru, antara guru dengan kepala sekolah dan antara guru dengan perguruan.

Mengembangkan etos kerja atau budaya kerja yang mengutamakan pelayanan bermutu tinggi kepada konsumen atau stakeholder

Cara yang dilakukan oleh guru untuk mengembangkan etos kerja atau budaya kerja yang mengutamakan pelayanan bermutu tinggi kepada konsumen/stakeholder adalah: (a) mengadakan konsultasi dengan orang tua ketika mengalami kesulitan tingkah laku, kesulitan belajar; b) membersihkan hati, menyayangi siswa, bekerja dengan ikhlas, menjadi guru itu belajar bersama siswa dan menjadi guru itu ladangnya amal; (c) berusaha mengungkapkan Matematika dengan menyenangkan; (d) membangun komunikasi dengan wali murid, dengan atasan, dengan relasi kerja, dan terutama dengan anak-anak; (e) komunikasi dengan orang tua melalui home visit ke rumahnya untuk mencari penyebabnya jika prestasi siswa menurun; (f) mengajar dengan maksimal, dan menjalin komunikasi yang baik dengan orang 
tua, dengan teman sejawat, dan dengan pimpinan. Filosofi bahwa bekerja menjadi guru adalah ibadah.

Mengadopsi inovasi atau mengembangkan kreativitas dalam pemanfaatan teknologi komunikasi dan informati mutakhir agar senantiasa tidak ketinggalan dalam kemampuannya mengelola pembelajaran.

Upaya yang dilakukan guru untuk mengembangkan kreatifitas dalam pemanfaatan teknologi komunikasi dan informasi mutakhir diantaranya adalah: (1) belajar Program-Program Komputer; (2) penggunaan LCD atau download dari Youtube; (3) guru memakai komputer untuk searching game; (4) penguasaan bahasa Inggris akan memudahkan penguasaan IT; (5) mengadakan lomba penggunaan IT bagi para guru untuk pembelajaran.

Berdasarkan penelitian, maka upaya guru dalam peningkatan kompetensi di Sekolah Dasar Budi Mulia Dua Seturan Depok Sleman: (a) memahami tuntutan standar profesi yang ada; (b) mencapai kualifikasi dan kompetenssi yang diharapkan; (c) membangun hubungan kesejawatan yang baik dan luas lewatorganisasi profesi; (d) mengembangkan etos kerja atau budaya kerja yang mengutamakan pelayanan bermutu tinggi kepada konsumen atau stakeholder; (e) mengadopsi inovasi atau mengembangkan kreativitas dalam pemanfaatan teknologi komunikasi dan informasi mutakhir agar senantiasa tidak ketinggalan dalam kemampuannya mengelola pembelajaran.

Berdasarkan hasil penelitian, upaya guru dalam peningkatan kompetensi di Sekolah Dasar Budi Mulia Dua Seturan Depok Sleman ternyata sesuai dengan pendapat Daryanto (2013, p.115) yang mengatakan bahwa upaya-upaya yang dilakukan oleh guru untuk meningkatkan profesionalismenya yaitu guru harus selalu berusaha untuk melakukan hal-hal sebagai berikut: Pertama, memahami tuntutan standar profesi yang ada, Kedua mencapai kualifikasi dan kompetensi yang dipersyaratkan, Ketiga, membangun hubungan kesejawatan yang baik dn luas termasuk lewat organisasi profesi. Keempat, mengembangkan etos kerja atau budaya kerja yang mengutamakan pelayanan bermutu tinggi kepada konsumen, Kelima, mengadopsi inovasi atau mengembangkan kreativitas dalam pemanfaatan teknologi komunikasi dan informasi mutakhir agar senantiasa tidak ketinggalan dalam kemampuannya mengelola pembelajaran.

Teori yang disampaikan Daryanto sesuai dengan temuan penelitian di Sekolah Dasar Budi Mulia Dua, bahkan peneliti menemukan nilai plus dari hasil penelitian tersebut. Upaya peningkatkan profesionalismenya sudah dilakukan para guru. Hal tersebut dilakukan untuk dapat memberikan pelayanan kepada peserta didik agar mereka menjadi peserta didik yang selaras dengan tujuan sekolah.

Faktor Pendukung \& Penghambat Peningkatan Kompetensi Guru Di Sekolah Dasar Budi Mulia Dua Seturan Depok Sleman

Berdasarkan temuan penelitian tersebut, maka faktor pendukung dan penghambat peningkatan kompetensi guru di Sekolah Dasar Budi Mulia Dua adalah sebagai berikut.

\section{Faktor Pendukung Peningkatan Kompetensi Guru}

Ada Dua faktor yang mempengaruhi tingkat kompetensi guru di sekolah Budi Mulia Dua yaitu faktor yang berasal dari dalam diri guru (internal) dan faktor yang berasal dari luar diri guru (eksternal).

Faktor internal meliputi: (1) tingkat pendidikan, bahwa semua guru sudah memenuhi standar kualifikasi yang dipersyaratkan Permendiknas No. 16 tahun 2007 yaitu semua guru memiliki pendidikan minimal Strata-1. Keberadaan para guru di Budi Mulia yang memiliki tingkat pendidikan minimal sarjana tidak menjadi penghambat peningkatan kompetensi guru. Bahkan ada 5 orang guru yang berusaha melanjutkan ke Strata-2, sehingga usaha tersebut bukan merupakan penghambat, justru merupakan usaha untuk meningkatkan kompetensinya; (2) keikutsertaan guru dalam berbagai pelatihan dan kegiatan 
ilmiah. Para guru sangat aktif dalam mengikuti berbagai pelatihan maupun kegiatan ilmiah. Hal ini terbukti dengan banyaknya kegiatan yang diikuti oleh para guru baik kegiatan pelatihan yang diadakan oleh Dinas, oleh LPMP, P4TK, Universitas maupun yang diadakan oleh swasta; (3) masa kerja dan pengalaman kerja. Masa kerja dan pengalaman kerja guru selalu di update dengan mengikuti berbagai pelatihan yang ada. Bagian SDM mengemukakan bahwa masa kerja dan pengalaman kerja tidak menjadi penghambat peningkatan kompetensi guru; (4) tingkat kesejahteraan. Tingkat kesejahteraan guru sudah mencukupi karena kesejahteraan guru sudah diatur oleh bagian HRD yayasan yaitu ada gaji dan tunjangan, kenaikan gaji berkala, per dua tahun dan per lima tahun; (5) kesadaran akan kewajiban dan panggilan hati nurani untuk menjadi guru yang profesional.

Faktor eksternal meliputi: (1) besar gaji dan tunjangan yang diterima. Para guru dalam bekerja tidak hanya memikirkan gaji atau tunjangan, tetapi lebih kepada bagaimana seorang guru mampu mengaplikasikan ilmu kepada siswa-siswanya. Tunjangan yang diperoleh guru sangat relatif, tetapi dari kesejahteraan keilmuan, kepuasan profesi sangat sejahtera. Vitamin-vitamin keprofesian selalu diperoleh guru dengan berbagai pelatihan yang diadakan; (2) ketersediaan sarana dan media penunjang pembelajaran. Ketersediaan sarana dan media penunjang pembelajaran sangat mendukung tugas-tugas guru. Para guru sangat terbantukan sekali dengan adanya komputer dan LCD yang sangat menunjang pembelajaran dan dalam membuat raport untuk siswa; (3) kepemimpinan kepala sekolah; (4) kegiatan pembinaan yang dilakukan. Kegiatan pembinaan yang dilakukan terhadap guru SD Budi Mulia tidak menjadi penghambat peningkatan kompetensi guru, justru kepala sekolah sangat mendukung. Adanya fasilitas internet, sharing antara guru lebih leluasa, dan setiap ada pelatihan di sharekan, justru tidak jadi penghambat; (5) peran serta masyarakat (wali Murid). Peran serta masyarakat dalam peningkatan kompetensi guru sangat mendukung sekali. Komite merupakan bagian dari masyarakat. Sedangkan yang menjadi komite adalah wali dari siswa, dengan demikian sangat mendukung program-program sekolah terutama dalam peningkatan kompetensi para guru.

Faktor-faktor tersebut saling terkait, meskipun peranannya bertingakat. Ada yang merupakan faktor utama dan ada yang merupakan faktor pendukung. Betapa pun besarnya peran kepala sekolah, tingkat keberhasilan tetap lebih ditentukan faktor internal guru itu sendiri.

Faktor Penghambat Peningkatan Kompetensi Guru di Sekolah Dasar Budi Mulia Dua Seturan Depok Sleman adalah Waktu Pelatihan

Waktu pelatihan yang diselenggarakan dari pihak luar sekolah seperti LPMP. PPPPTK, Dinas Pendidikan, dan pihak swasta maupun Universitas telah ditentukan oleh penyelenggara dan dilaksanakan pada jam-jam pembelajaran berlangsung. Kriteria bagi peserta pelatihan harus sesuai persyaratan dari penyelenggara. Sedangkan waktu pelatihan yang diselenggarakan oleh pihak sekolah menggunakan waktu setelah selesai pembelajaran. KKG bisa datang semua karena dilaksanakan pada hari sabtu dan Sekolah Dasar Budi Mulia Sabtu libur.

Berdasarkan penelitian, maka faktor pendukung dan penghambat peningkatan kompetensi guru di Sekolah Dasar Budi Mulia Dua adalah sebagai berikut.

Faktor Pendukung Peningkatan Kompetensi Guru

Ada dua faktor yang mempengaruhi tingkat kompetensi guru, yaitu faktor yang berasal dari dalam diri guru (intern) dan faktor yang berasal dari luar diri guru (eksternal).

a. Faktor internal antara lain: tingkat pendidikan, keikutsertaan guru dalam berbagai pelatihan dan kegiatan ilmiah, masa kerja dan pengalaman kerja, tingkat kesejahteraan, kesadaran akan kewajiban dan panggilan hati nurani untuk menjadi guru yang profesional. 
b. Faktor eksternal: besar gaji dan tunjangan yang diterima, ketersediaan sarana dan media penunjang pembelajaran, ketersediaan sarana dan media penunjang pembelajaran, kepemimpinan kepala sekolah, kegiatan pembinaan yang dilakukan, peran serta masyarakat (wali murid).

Faktor Penghambat Peningkatan Kompetensi Guru Di Sekolah Dasar Budi Mulia Dua Seturan Depok Sleman adalah Waktu Pelatihan. Waktu pelatihan yang diselenggarakan dari pihak luar sekolah seperti LPMP. PPPPTK, Dinas Pendidikan, dan pihak swasta maupun Universitas telah ditentukan oleh penyelenggara dan dilaksanakan pada jam-jam pembelajaran berlangsung. Kriteria bagi peserta pelatihan harus sesuai persyaratan dari penyelenggara. Sedangkan waktu pelatihan yang diselenggarakan oleh pihak sekolah menggunakan waktu setelah selesai pembelajaran. KKG bisa datang semua karena dilaksanakan pada hari sabtu dan Sekolah Dasar Budi Mulia Sabtu libur.

Berdasarkan hasil penelitian, upaya guru dalam peningkatan kompetensi $\mathrm{Di}$ Sekolah Dasar Budi Mulia Dua Seturan Depok Sleman ternyata sesuai dengan teori yang dikemukakan oleh Aan Hasanah (2012, p.51) bahwa ada dua faktor yang mempengaruhi tingkat kompetensi guru, yaitu faktor yang berasal dari dalam diri guru (internal) dan yang berasal dari luar diri guru (eksternal). Faktor internal meliputi: (a) tingkat pendidikan; (b) keikutsertaan dalam berbagai pelatihan dan kegiatan ilmiah; (c) masa kerja dan pengalaman kerja; (d) tingkat kesejahteraan,e) kesadaran akan kewajiban dan panggilan hati nurani. Sedangkan faktor eksternal yang mempengaruhi tingkat kompetensi guru meliputi: (1) besar gaji dan tunjangan yang diterima; (2) ketersediaan sarana dan media pembelajaran, (3) kepemimpinan kepala sekolah, (4) kegiatan pembinaan yang dilakukan, (5) peran serta masyarakat.

Teori yang disampaikan Aan Hasanah tersebut sesuai dengan temuan penelitian di Sekolah Dasar Budi Mulia Dua, bah- kan peneliti menemukan nilai plus dari hasil penelitian tersebut. Hasil penelitian menunjukkan bahwa baik faktor internal maupun eksternal tidak menjadi penghambat peningkatan kompetensi guru. Justru faktor internal dan eksternal merupakan pendukung peningkatan kompetensi guru di Sekolah Dasar Budi Mulia Dua. Penghambatnya adalah waktu pelatihan yang diselenggarakan dari pihak luar sekolah seperti LPMP, PPPPTK, Dinas Pendidikan, dan pihak swasta maupun Universitas telah ditentukan oleh penyelenggara dan dilaksanakan pada jam-jam pembelajaran berlangsung. Sedangkan kelas tidak boleh kosong, sehingga harus mewakilkan. Solusinya, sekolah harus bisa mengelola waktu dengan bijaksana.

Upaya yang Dilakukan oleh Kepala Sekolah dalam Mengatasi Hambatan Pelaksanaan Peningkatan Kompetensi Guru di Sekolah Dasar Budi Mulia Dua Seturan Depok Sleman

Kepemimpinan kepala sekolah memiliki andil besar dalam mendorong dan meningkatkan kompetensi guru. Hampir semua kepala sekolah telah berusaha untuk menunjukkan tanggung jawab untuk memajukan pendidikan, tetapi belum semuanya mampu membangkit semangat guru untuk memiliki komitmen kuat terhadap profesinya.

Memfasilitasi dan Memberikan Kesempatan yang Luas Kepada Para Guru untuk Dapat Melaksanakan Kegiatan Pengembangan Profesi Melalui Berbagai Kegiatan Pendidikan dan Pelatihan Yang Dilaksanakan di Sekolah

Workshop Narasi adalah cara bagaimana membuat raport yang tidak hanya ke angka tetapi narasi perbidang studi yang tidak kalah pentingnya bagi guru, karena raport merupakan bagian layanan akademik kepada siswa terutama kepada orang tua siswa. Untuk itu dalam pembuatan raport narasi bahasa yang dibuat harus benar, baik dari segi kaidah bahasa maupun tata bahasanya. 
Melalui Kegiatan Pendidikan dan Pelatihan Yang Dilaksanakan di Luar Sekolah.

Salah satu guru Matematika kelas 3 pernah dikirim oleh sekolah mengikuti pelatihan Proyek learning Curiculum for Children (PLCC) di Solo pada tahun 2009 dari Diknas di Solo, seminar di University Club (UC) UGM tentang mengajar dengan cinta, whorkshop Matematika dahsyat awal bulan September 2013 di UNY, dan studi banding di Jakarta di SD Al-Jannah. Pelatihan di Jakarta Internasional School (JIS) tentang pembelajaran yang haqiqi khususnya IPA sebagai TOT, pelatihan tentang bagaimana cara komunikasi yang efektif dengan NLP (Neuro Linguistic Program).

Berdasarkan temuan penelitian tersebut, maka upaya yang dilakukan oleh kepala sekolah dalam mengatasi hambatan pelaksanaan peningkatan kompetensi guru di Sekolah Dasar Budi Mulia Dua Seturan Depok Sleman adalah:

a. Memfasilitasi dan memberikan kesempatan yang luas kepada para guru untuk dapat melaksanakan kegiatan pengembangan profesi melalui berbagai kegiatan pndidikan dan pelatihan yang dilaksanakan di sekolah

b. Melalui kegiatan pendidikan dan pelatihan yang dilaksanakan di luar sekolah.

Berdasarkan hasil penelitian, ternyata upaya yang dilakukan oleh Kepala Sekolah dalam mengatasi hambatan pelaksanaan peningkatan kompetensi guru di Sekolah Dasar Budi Mulia Dua Seturan Depok Sleman adalah: memfasilitasi dan memberikan kesempatan yang luas kepada para guru untuk dapat melaksanakan kegiatan pengembangan profesi melalui berbagai kegiatan pendidikan dan pelatihan yang dilaksanakan di sekolah dan kegiatan di luar sekolah melalui kegiatan pendidkan dan pelatihan yang dilaksanakan di luar sekolah.

Upaya-Upaya yang Dilakukan Oleh Guru Dalam Mengatasi Hambatan Pelaksanaan Peningkatan Kompetensi Guru di Sekolah
Dasar Budi Mulia Dua Seturan Depok Sleman

Melanjutkan Studi Ke Jenjang yang Lebih Tinggi

Para guru memiliki keinginan kuat untuk melanjutkan studi ke strata-2. Jika ada beasiswa atau dibiayai perguruan bahkan sampai potong gaji pun mereka bersedia

Keikutsertaan Dalam Berbagai Pelatihan dan Kegiatan Ilmiah

Sekolah Budi Mulia Dua selalu mengikutsertakan para guru ke pelatihan, seminar, dan kegiatan ilmiah lainnya. Hal tersebut dapat dilihat dari dokumen sekolah Budi Mulia Dua dalam daftar guru yang ditugaskan ke luar. Banyaknya ragam pelatihan yang diikuti guru, akan dapat meningkatkan kualitas pembelajaran yang berkontribusi terhadap prestasi siswa.

Kesadaran akan kewajiban dan panggilan hati nurani untuk menjadi guru yang profesional.

Kesadaran akan kewajiban dan panggilan hati nurani untuk menjadi guru profesional sudah ada pada diri para guru di Sekolah Dasar Budi Mulia Dua. Antara lain dengan mempelajari teknologi, apalagi teknologi yang terkini, lebih membuka diri, belajar hal-hal yang baru, belajar terus untuk lebih profesional.

Mencari Spesialisasi Bidang Ilmu yang Di Ajarkan

Usaha yang dilakukan guru untuk mencari spesialisasi bidang ilmu yang diajarkan adalah melanjutkan studi ke Strata-2, selalu belajar dan mencari spesialisasi bidang ilmu yang diajarkan serta mencari sumber-sumber pembelajaran dari internet. Selain itu guru juga memperdalam Matematika, memperdalam Psikologi anak dengan banyak membaca buku.

Melaksanakan Kegiatan-Kegiatan Mandiri yang Relevan Dengan Tugas Keprofesiannya.

Kegiatan mandiri yang relevan dengan tugas keprofesian seorang guru seperti yang dilakukan salah satu guru Matematika selain banyak membaca buku, 
juga memiliki kesibukan lain yaitu mengajar SMA di Newtron. Adapun tujuannya adalah untuk mengetahui kelemahan dalam Matematika anak SMA, sehingga harus dimatangkan konsepnya di SD.

Mengembangkan Materi dan Metodologi yang sesuai dengan Kebutuhan Pengajaran.

Ketika mengajar guru mengambil materi dari beberapa buku yang berbeda dan mencari yang paling mudah dan masuk akal sehingga mudah diterima siswa. Selain itu sengaja browsing di internet untuk materi-materi dan informasi mengenai workshop, mencari bahan ajar lewat internet. Kalau metode melalui komunikasi efektif kepada siswa dan memahami kondisi psikologis siswa.

Mengikuti Program Pembinaan Keprofesian secara Khusus, Misalnya Program Akta, Sertifikasi, dan Sebagainya

Para guru mengikuti program pembinaan keprofesian secara khusus misalnya mengambil program akta, dan sertifikasi. Salah satu guru mengikuti program Akta IVdi UAD untuk menunjang keprofesiannya karena guru tersebut berasal dari Fisika UGM. Ada pula guru yang menempuh sertifikasi. Usaha yang dilakukan oleh para guru tersebut baik dengan mengambil Program Akta IV maupun menempuh sertifikasi merupakan bagian dari usaha meningkatkan kompetensi seorang guru.

Upaya yang dilakukan guru dalam mengatasi hambatan pelaksanaan peningkatan kompetensi guru di Sekolah Dasar Budi Mulia Dua Seturan Depok Sleman adalah: (a) melanjutkan studi ke jenjang yang lebih tinggi; (b) keikutsertaan dalam berbagai pelatihan dan kegiatan ilmiah; (c) kesadaran akan kewajiban dan panggilan hati nurani untuk menjadi guru yang profesional; (d) mencari spesialisasi bidang ilmu yang di ajarkan; (e) melaksanakan kegiatan-kegiatan mandiri yang relevan dengan tugas keprofesiannya; (f) mengembangkan materi dan metodologi yang sesuai dengan kebutuhan pengajaran; (g) mengikuti program pembinaan keprofesi- an secara khusus, misalnya program akta, sertifikasi, dan sebagainya.

Berdasarkan hasil penelitian, upaya yang dilakukan guru dalam mengatasi hambatan pelaksanaan peningkatan kompetensi Di Sekolah Dasar Budi Mulia Dua Seturan Depok Sleman ternyata sesuai dengan teori yang dikemukakan oleh $\mathrm{Mu}$ hammad Nurdin (2005, p.110) yang menyatakan bahwa untuk meningkatkan profesi guru dapat dilakukan dengan cara:

a. Sendiri-sendiri, yaitu dengan jalan:

Menekuni dan mempelajari secara kontinu pengetahuan-pengetahuan yang berhubungan dengan teknik atau proses belajar mengajar secara umum. Misalnya, pengetahuan tentang Proses Belajar Mengajar (PBM) atau ilmu-ilmu lainnya yang dapat meningkatkan tugas keprofesiannya.

1) Mencari spesialisasi bidang ilmu yang diajarkan.

2) Melakukan kegiatan-kegiatan mandiri yang relevan dengan tugas keprofesiannya.

3) Mengembangkan materi dan metodologi yang sesuai dengan kebutuhan pengajaran.

b. Secara bersama-sama dapat dilakukan, misalnya dengan:

1) Mengikuti berbagai bentuk penataran dan lokakarya.

2) Mengikuti program pembinaan keprofesian secara khusus, misalnya program akta, sertifikasi, dan lain sebagainya.

Teori yang disampaikan Muhmmad Nurdin yang menyatakan untuk meningkatkan profesi guru dapat dilakukan dengan carasendiri-sendiri maupun bersamasama merupakan cara untuk mengatasi hambatan pelaksanaan peningkatan kompetensi gurudi Sekolah Dasar Budi Mulia Dua. Peneliti menemukan nilai plus dari hasil penelitian tersebut.

Adapun upaya guru dalam mengatasi hambatan waktu pelatihan yang bersamaan dengan jam belajar efektif bahwa antara guru saling koordinasi menukar jam, kalau terpaksanya tidak bisa guru tersebut meninggalkan tugas yang tidak memberatkan 
guru lain. Di sekolah Budi Mulia antara guru saling mendukung.

Adapun hasil peningkatan kompetensi profesional guru di Sekolah Dasar Dudi Mulia Dua dapat dilihat pada Tabel 1.

Tabel 1. Daftar Prestasi Guru SD Budi Mulia Dua Tahun 2013/2014

\begin{tabular}{|c|c|c|c|}
\hline No & NAMA GURU & PRESTASI & TAHUN \\
\hline 1. & Sari Wulandari & $\begin{array}{l}\text { Juara } 1 \text { lomba guru berprestasi tingkat } \\
\text { kecamatan Depok. } \\
\text { Juara } 4 \text { lomba guru berprestasi tingkat } \\
\text { kabupaten Sleman }\end{array}$ & 2013 \\
\hline 2. & Ratna Harmini & $\begin{array}{l}\text { Juara } 2 \text { lomba kepala sekolah berprestasi } \\
\text { tingkat kecamatan Depok. }\end{array}$ & 2013 \\
\hline 3. & Yulita Varani & $\begin{array}{l}\text { Juara harapan } 3 \text { lomba menulis cerpen di } \\
\text { majalah BOBO. }\end{array}$ & 2013 \\
\hline 4. & Ema Romayah & $\begin{array}{l}\text { Juara } 1 \text { lomba model pembelajaran } \\
\text { pendidikan nilai di sekolah inklusi oleh } \\
\text { LPM UNY. }\end{array}$ & 2013 \\
\hline 5. & lis Wiyanto & $\begin{array}{l}\text { Sepuluh besar lomba pembuatan alat } \\
\text { peraga yang diselenggarakan oleh LPMP } \\
\text { tingkat DIY. }\end{array}$ & 2013 \\
\hline 6. & Eko Budi Santoso & $\begin{array}{l}\text { Sepuluh besar lomba pembuatan alat } \\
\text { peraga yang diselenggarakan oleh LPMP } \\
\text { tingkat DIY. }\end{array}$ & 2013 \\
\hline
\end{tabular}

Berdasarkan Tabel 1 di atas dapat dijelaskan bahwa guru yang mismatch maupun yang match ternyata sama-sama memiliki prestasi yang bisa diandalkan dalam meningkatkan kualitas pembelajaran yang berkontribusi terhadap prestasi siswa. Hal ini dibuktikan bahwa prestasi akademik maupun non akademik dengan hasil baik. Juga didukung kesadaran bahwa bekerja menjadi guru itu ladangnya ibadah, bekerja dengan ikhlas, menjadi guru kreatif yang mengajar dengan hati, dan menjadi guru itu belajar bersama anak. Bisa dikatakan bahwa guru bekerja itu selalu diikuti dengan niat ibadah.

\section{Simpulan dan Saran}

Simpulan

Kesimpulan penelitian ini adalah bahwa Sekolah Dasar Budi Mulia Dua melakukan upaya peningkatan kompetensi profesional para guru sebagai berikut :

1. Upaya yang dilakukan kepala sekolah meliputi mengirimkan para guru mengikuti berbagai pelatihan dan kegiatan ilmiah, mengadakan sosialisasi hasil pelatihan, memotivasi untuk meningkatkan kompetensi, memberikan reward bagi guru yang berprestasi.
2. Upaya para guru diantaranya memahami tuntutan standar profesi, mencapai kualifikasi dan kompetensi, mengembangkan etos kerja dan budaya kerja yang mengutamakan pelayanan bermutu tinggi kepada konsumen. Filosofi bahwa bekerja menjadi guru adalah ibadah.

3. Faktor pendukung peningkatan kompetensi guru antara lain faktor internal dan eksternal. Faktor penghambatnya karena sekolah tersebut menerapkan full day school, sehingga pelatihan yang dilaksanakan di luar sekolah waktunya bersamaan dengan jam pembelajaran efektif.

4. Upaya kepala sekolah dalam mengatasi hambatan peningkatan kompetensi guru dengan memfasilitasi dan memberikan kesempatan yang luas untuk melaksanakan pengembangan profesi, sedangkan upaya dalam mengatasi hambatan waktu pelatihan dengan membuat jadwal pengganti bagi guru yang diikutsertakan ke pelatihan, membuat jadwal tersendiri di luar jam pembelajaran.

5. Upaya para guru dalam mengatasi hambatan diantaranya dengan melanjutkan ke Strata-2, keikutsertaan dalam berbagai pelatihan dan kegiatan ilmiah. Sedangkan upaya dalam mengatasi hambatan waktu pelatihan yang bersamaan dengan jam mengajar bahwa antara guru saling menukar jadwal mengajar. Alternatif selain tukar jadwal mengajar, yang dilakukan adalah memberikan tugas ke siswa yang tidak memberatkan guru lain.

Saran

Saran dari hasil penelitian ini adalah:

1. Disarankan bagi Dinas Pendidikan Pemuda dan Olahraga Kabupaten Sleman dapat memberikan perhatian dengan mengadakan pelatihan yang dapat menunjang peningkatan kompetensi guru, sehingga kualitas pembelajaran menjadi lebih baik. 
2. Disarankan kepada kepala sekolah di sekolah Dasar Budi Mulia Dua dapat dijadikan bahan refleksi untuk selalu berusaha meningkatkan kualitas pelatihan, workshop, seminar, diklat, sehingga meningkatkan kompetensi para guru.

3. Disarankan kepada para guru di Sekolah Dasar Budi Mulia Dua dapat dijadikan bahan refleksi untuk selalu berusaha meningkatkan kompetensi dan profesionalisme sebagai seorang guru.

4. Disarankan untuk meningkatkan manajemen waktu antara pembelajaran dengan pelaksanaan pelatihan, sehingga jadwal tidak berbenturan.

\section{Daftar Pustaka}

Aan Hasanah. (2012). Pengembangan profesi guru, Bandung: Pustaka Setia

Bungin, B.(2012). Analisis data penelitian kualitatif: pemahaman filosofis dan metodologis ke arah penguasaan model aplikasi. Jakarta: PT Raja GrafindoPersada.

Darling-Hammond.(2006). The Competent Te-acher. Diakses 13 Desember 2014 dari

http://www.dikti.go.id/files/atur $\angle$ Permen162007KompetensiGuru.pdf,
Daryanto. (2013). Standar kompetensi dan Penilaian kinerja guru profesional. Yogyakarta: Gava Media

Komara, E. (2012). Penelitian tindakan kelas dan peningkatan profesionalitas guru. Bandung: PT Refika Aditama.

Liakopoulou, M. (2011).The Professional Competence of Teachers: Which qualities, attitudes, skills and knowledge contribute to a teacher's effectiveness? Aristotle University of Thessaloniki Makedonomaxo: International Journal of Humanities and Social Science Vol. 1 No. 21 [Special Issue December 2011

Miles, M. B., \& Huberman, A. M. (1992). Qualitative data analysis. London: Sage Publication (Terjemahan Tjetjep Rohendi Rohidi) Jakarta: Universitas Indonesia (UI-Press).

Nurdin, M. (2005). Kiat menjadi guru profesional. Jakarta: Azura Media

Depdiknas. (2007). Peraturan Pemerintah RI No.16, Tahun 2007, Tentang Standar Kualifikasi Akademik dan Kompetensi Guru. Diakses pada tanggal 12 Desember 2014 dari http://www.dikti.go.id/files/atur /Permen162007KompetensiGuru.pdf, 